\title{
A proposal for body donation forms in Turkey: study of the Committee for Body Donation and Cadaver Monitoring
}

\section{On behalf of the Committee for Body Donation and Cadaver Monitoring of the Turkish Society of Anatomy and Clinical Anatomy}

\author{
Illke Ali Gürses ${ }^{1}$ (D), Servet Çelik² (D), Mehmet Üzel ${ }^{3}$ (D), Çağatay Barut ${ }^{4}$ (D), Zeliha Kurtoğlu Olgunus ${ }^{5}$ (D), \\ Okan Bilge $^{2}$ iD \\ ${ }^{1}$ Department of Anatomy, Istanbul Faculty of Medicine, Istanbul University, İstanbul, Turkey \\ ${ }^{2}$ Department of Anatomy, School of Medicine, Ege University, Izmir, Turkey \\ ${ }^{3}$ Department of Anatomy, Cerrahpaşa Faculty of Medicine, Istanbul University-Cerrahpassa, Istanbul, Turkey \\ ${ }^{4}$ Department of Anatomy, School of Medicine, Bahçessehir University, İstanbul, Turkey \\ ${ }^{5}$ Department of Anatomy, School of Medicine, Mersin University, Mersin, Turkey
}

\begin{abstract}
Informed consent is an integral part of daily anatomical practice. Providing adequate information regarding body donation process and emphasizing the importance of use of donated bodies in anatomy education will help the individuals who consider body donation. Current legislation that regulates body donation in Turkey does not provide details on the consent process. Additionally, recent research showed that registered Turkish body donors have various opinions on the use of their bodies, sharing their personal information with the departments and medical students, and retention time of their bodies or body parts. This resulted in non-standard or modified donation forms across different institutions. Therefore, the Turkish Society of Anatomy and Clinical Anatomy (TSACA) decided that a standard and more comprehensive body donation form that addresses contemporary topics was necessary. The newly established Committee for Body Donation and Cadaver Monitoring has been assigned with this task. As of May 2020, the Committee had finalized the updated body donation form according to departmental feedback and donors' opinions. This paper outlines the existing data and reasons along with the legal grounds for the current update.
\end{abstract}

Keywords: body donation; body donation form; informed consent; legislation; Turkey

Anatomy 2020;14(3):220-226 (02020 Turkish Society of Anatomy and Clinical Anatomy (TSACA)

\section{Importance of Anatomy Education and Body Donation}

Anatomy is a fundamental part of modern undergraduate medical education ${ }^{[1]}$ and frequently preferred for postgraduate medical training. ${ }^{[2]}$ Using human bodies in anatomy education helps students to acknowledge the three dimensional structure of the body ${ }^{[3]}$ acquire basic medical skills, ${ }^{[4]}$ and reflect on the concepts such as normality, pathology, and variation. ${ }^{[5]}$ Additionally, hidden curricular processes such as professionalism, ${ }^{[6]}$ team-work abilities, ${ }^{[3]}$ and human skills ${ }^{[7]}$ are also gained. Nevertheless, hidden curricular gains of using cadavers are usually associated with the use of donor cadavers. ${ }^{[8]}$ This aspect of anatomy practice emphasizes the importance of body donation programs throughout the world..$^{[9,10]}$

\section{Body Procurement and Legislation in Turkey}

Unclaimed bodies still constitute the major source of bodies for anatomy education and scientific research in Turkey. ${ }^{[10,11]}$ Sporadic cases of body donation continued 
since the enactment of the Act 2238. ${ }^{[1,12]}$ Therefore, the Turkish Society of Anatomy and Clinical Anatomy (TSACA) implemented a National Anatomy Week in 2012 and started a campaign that aimed to promote body donation among the general population. ${ }^{[13]}$ The campaign seemed to have an effect because a promising increase was present in body donation registrations and donations since 2012. ${ }^{[11]}$

The first legal regulation on body procurement in Turkey was enacted in 1979 as the Act 2238. ${ }^{[14]}$ Although initially the Act aimed to regulate organ and tissue donation and transplantation, article 14 included the use of unclaimed bodies of individuals who passed away in state hospitals as cadavers. In 1982, willing donation of one's body before death had been added with an amendment, ${ }^{[14]}$ probably following the first ever-recorded body donation case of Cavit Cav. ${ }^{[15]}$ Same year, an accompanying regulation was issued that exclusively authorized anatomy departments for body procurement in Turkey. ${ }^{[16]}$ With the increasing number of medical faculties and declining body sources, importation of bodies was allowed with another amendment in 2014. ${ }^{[14]}$

As in all medical procedures, obtaining informed consent is also crucial for anatomy practice. ${ }^{[17,18]}$ Despite unclaimed bodies constituting the major source of bodies in Turkey, encouraging and promoting body donation resulted in increased interest of the public in body donation. ${ }^{[1]}$ Nevertheless, current legislation and body donation forms do not cover detailed information as suggested by the literature. ${ }^{[19,20]}$ Given the recent data on donor opinions in Turkey regarding contemporary topics such as sharing personal information and retention time of bodies ${ }^{[12]}$ and discussions on updating current body donation forms ${ }^{[1,2,2]}$ the TSACA was aimed to address this situation.

\section{Establishment of the Committee for Body Donation and Cadaver Monitoring}

At the Extraordinary General Assembly of the TSACA during the 2019 Winter Meeting in Denizli, the Committee for Body Donation and Cadaver Monitoring (CBDCM) that consists of thirteen members was created. ${ }^{[2]]}$ The Committee organized two meetings during the National Anatomy Congress in August 2019 and agreed upon a variety of topics to work on. One of these topics was the need for an update on body donation forms.

Initially, a substantial search was done to outline the formats of existing body donation forms around the world and local studies that provide information on donors' opinions. ${ }^{[12,19]}$ The first draft with wider consent options of the form was distributed to committee members and the form was revised according to their feedback. This version was found to be confusing and limiting for the depart- ments, therefore a second version with consent sections on vital topics and an additional information leaflet was created. Following the second feedback session, a donor card section was added to the form. This version was agreed upon as the final version of the body donation form.

\section{Updated Body Donation Form}

Article 7 of the Act 2238 gives the responsibility to the physicians for informing the individuals who wish to donate their bodies. ${ }^{[14]}$ Therefore, the first component of the updated body donation form is the information leaflet, which aims to help anatomy departments to provide adequate information regarding body donation (Appendix 1). This document is not a guideline but only provides a framework for important information that is suggested to be disclosed to all individuals who consider body donation. It provides information on the definitions of body donation and cadaver, importance and use of human cadavers, embalming and storage procedures, dissection and research activities, protection of the donor's memory during these activities, and transportation of bodies following death and before burial. The activities that would be performed on bodies such as dissection and research activities, was not provided as an optional consent section due to donors' tendencies. Current literature shows that $88 \%$ to $98.9 \%$ of registered body donors either consented to both activities or left the decision to anatomy departments. ${ }^{[1,22]}$ One section that was removed from the initial draft of the form to the leaflet is the acquisition and use of digital images. Since all procured bodies are expected to be used in educational or research activities, documentation of relevant data through images (including photographs, videos, $3 \mathrm{D}$ images, and $3 \mathrm{D}$ print-outs) is very important. Therefore, instead of obtaining consent for this from all potential donors as an opt-in option, detailed information of acquiring and using digital images of donor-cadavers for educational and scientific purposes have been included in the leaflet. Adhering to ethical rules and respecting personal rights during this practice was highlighted. The leaflet also encourages donors to disclose their health records for anatomical education and research. Currently, the legislation regarding body procurement in Turkey does not define rejection criteria such as infectious diseases or obesity. ${ }^{[1,16]}$ Therefore, the leaflet warns potential donors for any existing rejection criteria of the institution, including current Covid-19 pandemic, that they should be informed beforehand. All institutions should keep in mind that the information leaflet is just a consensus framework of basic information to be disclosed. Therefore, departments could expand or modify its content if needed.

The second component of the updated form is the detailed informed consent form (Appendix 2). It provides a main consent section similar to the previous donation 
form and incorporates a donation statement and the names and signatures of the donor, two witnesses, and a department staff. The contact information of the donor, donor relatives, and the institution are also incorporated. The main section is mandatory due to the Act $2238 .^{[14]}$ Declaration of body donation could be considered as a final will. ${ }^{[1,23]}$ According to Article 538 of Act 4721 (Turkish Civil Code), ${ }^{[24]}$ the written will must be hand written and signed by the individual. Therefore, any form of printed document is invalid and has no legal value. ${ }^{[25]} \mathrm{On}$ the other hand, Article 6 of Act 2238 states that the individual can consent to body donation in two ways. First, one requires a signed handwritten statement in the presence of two witnesses. Secondly, the individual can sign a printed document following a verbal declaration in the presence of two witnesses and the confirmation of a physician. ${ }^{[14]}$ Therefore, the current form recommends the signatures of relatives as witnesses so that the document might gain the legal status of a will. According to the Turkish Civil Code, ${ }^{[2]}$ although the person loses all personal rights when they die ${ }^{[2]}$ some aspects of the personality such as the memory, dignity, and confidentiality of the person continues. ${ }^{[25,26]}$ In order to protect these aspects, the body of a person gains the status of heritage to the surviving relatives. ${ }^{[2]}$ This gives the surviving relatives the right to decide what will happen to one's body following her/his death. This legal aspect of body donation is crucial for realizing the final wish of a body donor. Therefore, the Committee advises all departments to encourage all possible donors to inform their relatives. Involving donor relatives to the donation process as witnesses is also encouraged because by doing this families and relatives are to be consulted during the donation procedure. ${ }^{[12,23]}$

Apart from the main consent section, the updated form obtains optional donor consent regarding contemporary topics including disclosing personal or health information of the donor, public display, and retention time of anatomic specimens. This section aims to provide an optin opportunity for possible donors regarding aforementioned topics. Turkish donors have shown to be open with the idea of their personal and health information to be shared with public and/or medical students. ${ }^{[12]}$ Health information could be used in daily anatomy education and research, while personal information could be used to promote body donation. Only $5.1 \%$ and $17.7 \%$ of Turkish donors wished their health and personal information, respectively, to be kept confidential. In order to adapt to donor wishes, these information were provided as optional consent sections.

It is known that the retention time of anatomical specimens may reach up to 25 to 50 years in some Turkish anatomy departments. ${ }^{[12]}$ Similarly, $94.7 \%$ of registered Turkish body donors either approved the indefinite use of their bodies or left this decision to the institutions. ${ }^{[12]}$ Therefore, this option was also provided in the consent form.

Currently, public access to anatomical collections and anatomical museums within departments in Turkey is not permitted. Nevertheless, with the increasing public interest in human anatomy ${ }^{[27]}$ and methods such as plastination to support this, ${ }^{[28]}$ publicly open collections or museums might considered in the future. In order to provide a legal basis for this practice, the updated form incorporated an optional consent section regarding public display of anatomical specimens for increasing an awareness on body donation and promoting the science of anatomy.

The detailed informed consent form also has an embedded donor card for donors' personal use. Since the actual donation form is bulky and is nearly impossible to be carried in a wallet or purse, a smaller donation card is prepared following previous examples ${ }^{[2]]}$ and the feedback of registered body donors at different institutions. This card provides ID and contact information of the donors, registration number at the given institution, a shorter consent section, and detailed contact of the institution, if needed. Although it should be kept in mind that this document is not the actual donation document and does not have legal value, ${ }^{[2]}$ but only serves as a more efficient information and contact source.

Current update achieved to create a standard and more comprehensive body donation form that addresses recent topics and donors' opinions. Nevertheless, institutional needs and expectations should be evaluated prior to incorporating the updated form into daily practice. Therefore, modifications to the updated form could be done if needed by the institutions. Additionally, departmental and individual feedback along with possible future legal regulations will result in a continuous improvement of the body donation form. Turkish and English versions of the information leaflet and body donation form are provided as supplemental files or can be downloaded from the official website of the TSACA (http://www.anatomidernegi.org.tr/).

\section{Conflict of Interest}

No conflict of interest was declared by the authors.

\section{Author Contributions}

All authors commonly participated in all steps of this work.

\section{Ethics Approval}

Ethics approval was not required since the study was not performed in humans or animals and no personal data was used. 


\section{Funding}

The authors declare that this work has not received any financial support.

\section{References}

1. Arraéz-Aybar LA, Sánchez-Montesinos I, Mirapeix RM, MonpeoCorredera B, Sañudo-Tejero JR. Relevance of human anatomy in daily clinical practice. Ann Anat 2010;192:341-8.

2. Cornwall J, Stringer MD. The wider importance of cadavers: educational and research diversity from a body bequest program. Anat Sci Educ 2009;2:234-7.

3. Lempp HK. Perceptions of dissection by students in one medical school: beyond learning about anatomy. A qualitative study. Med Educ 2005;39:318-25.

4. Cook MS, Kernahan PJ. An unembalmed cadaveric preparation for simulating pleural effusion: a pilot study of chest percussion involving medical students. Anat Sci Educ 2017;10:160-9.

5. Older J. Anatomy: a must for teaching the next generation. Surgeon 2004;2:79-90.

6. Zheng YHE, Palombella A, Salfi J, Wainman B. Dissecting through barriers: a follow-up study on the long-term effects of interprofessional education in a dissection course with healthcare professional students. Anat Sci Educ 2018;12:52-60.

7. Ghosh SK, Kumar A. Building professionalism in human dissection room as a component of hidden curriculum delivery: a systematic review of good practices. Anat Sci Educ 2019;12:210-21.

8. McMenamin PG, McLachlan J, Wilson A, McBride JM, Pickering J, Evans DJR, Winkelmann A. Do we really need cadavers anymore to learn anatomy in undergraduate medicine? Med Teach 2019;40: $1020-9$.

9. Riederer BM. Body donations today and tomorrow: what is best practice and why? Clin Anat 2016;29:11-8.

10. Habicht JL, Kiessling C, Winkelmann A. Bodies for anatomy education in medical schools: an overview of the sources of cadavers worldwide. Acad Med 2018;93:1293-300.

11. Gürses İA, Coşkun O, Öztürk A. Current status of cadaver sources in Turkey and a wake-up call for Turkish anatomists. Anat Sci Educ 2018;11:155-65.

12. Gürses İA, Ertaş A, Gürtekin B, Coşkun O, Üzel M, Gayretli Ö, Demirci MS. Profile and motivations of registered whole-body donors in Turkey: Istanbul University experience. Anat Sci Educ 2019;12:370-85.

13. Turkish Society of Anatomy and Clinical Anatomy. Ulusal Anatomi Haftası Basın Bildirgesi. [Internet]. [Retrieved on June 20, 2020]. Available from: http://www.anatomidernegi.org.tr/belgeler

14. T.C. Resmî Gazete. Organ ve Doku Alınması, Saklanması, Aşılanması ve Nakli Hakkında Kanun. 29 May 1979. Kanun Numarası:

ORCID ID:

I. A. Gürses 0000-0001-9188-4662; S. Çelik 0000-0002-1102-4417; M. Üzel 0000-0002-7184-4900; Ç. Barut 0000-0001-6999-5980; Z. Kurtoğlu Olgunus 0000-0003-0196-9975; O. Bilge 0000-0002-8993-2271
2238. [Internet]. [Retrieved on June 20, 2020]. Available from: http://www.mevzuat.gov.tr/MevzuatMetin/1.5.2238.pdf

15. Demirci $M$, Şahinoğlu S. A body dedicated to anatomy: Cavit Cav a first in Ankara University, School of Medicine, Department of Anatomy. Journal of Ankara University Faculty of Medicine 2017;70: 143-50.

16. T.C. Resmî Gazete. İnsan Cesedi Üzerinde Bilimsel Araştırma Yapılmasına İlişkin Yönetmelik. 17 June 1982. [Internet]. [Retrieved on June 20, 2020]. Available from: http://www.resmigazete.gov.tr/ arsiv/17727.pdf

17. Jones DG. Searching for good practice recommendations on body donation across diverse cultures. Clin Anat 2016;29:55-9.

18. Winkelmann A. Consent and consensus - Ethical perspectives on obtaining bodies for anatomical dissection. Clin Anat 2016;29:70-9.

19. Develi S. A detailed cadaver donation form. Anatomy 2018;12:38-44.

20. Gürses İA, Ertaş A, Gürtekin B, Coşkun O, Üzel M, Gayretli Ö, Demirci MS. Updating body donation forms. Anatomy 2018;12: S122.

21. Turkish Society of Anatomy and Clinical Anatomy. Kurullar ve Komiteler, 2019 [Internet]. [Retrieved on June 20, 2020]. Available from: http://www.anatomidernegi.org.tr/belgeler

22. Greene JR. Effects of detailed information about dissection on intentions to bequest bodies for use in teaching and research. J Anat 2003; 202:475-7.

23. Farsides T, Smith CF. Consent in body donation. Eur J Anat 2020; 24:239-48.

24. T.C. Resmî Gazete. Türk Medeni Kanunu. 22 November 2001. Kanun Numarasi: 4721. [Internet]. [Retrieved on June 20, 2020]. Available from: https://www.mevzuat.gov.tr/MevzuatMetin/1.5. 4721.pdf

25. Parlak Ş. Organ bağışı ve organ naklinde ortaya çıkan sorunlar. Journal of Turkish Medical Association 2009;83:189-222.

26. Özel Ç. Medeni hukuk açısından ölüm anının belirlenmesi ve ceset üzerindeki hakka ilişkin bazı düşünceler. Journal of Ankara University Faculty of Law 2002;51:43-77.

27. Milliyet. Body Worlds rekorla veda etti. Milliyet 31 March 2011. [Internet]. [Retrieved on June 20, 2020]. Available from: https:// www.milliyet.com.tr/gundem/body-worlds-rekorla-veda-etti1371457

28. Bilge O, Çelik S, Boduç E. Uzun yıllar önce tespiti yapılmış lokomotor sistem örneklerinin plastinasyonu ve eğitimde kullanımı. Ege Journal of Medicine 2014;53:84-7.

29. Mersin Üniversitesi Tip Fakültesi Anatomi Anabilim Dalı. Kadavra bağışı hakkında bilgi. 2020. [Internet]. [Retrieved on June 20, 2020]. Available from http://www.mersin.edu.tr/haberler/327402/kadavrabagisi-hakkinda-bilgi

Correspondence to: Ilke Ali Gürses, MD Department of Anatomy, Istanbul Faculty of Medicine, Istanbul University, 34093, Fatih, Istanbul, Turkey Phone: +902124142176 e-mail: iagurses@gmail.com

Conflict of interest statement: No conflicts declared.

This is an open access article distributed under the terms of the Creative Commons Attribution-NonCommercial-NoDerivs 4.0 Unported (CC BY-NCND4.0) Licence (http://creativecommons.org/licenses/by-nc-nd/4.0/) which permits unrestricted noncommercial use, distribution, and reproduction in any medium, provided the original work is properly cited. How to cite this article: Gürses İA, Çelik S, Üzel M, Barut Ç, Kurtoğlu Olgunus Z, Bilge O. A proposal for body donation forms in Turkey: study of the Committee for Body Donation and Cadaver Monitoring. Anatomy 2020;14(3):220-226. 
Appendix 1a

Body donation information leaflet in English.

UNIVERSITY

AMBLEM

\section{UNIVERSITY \\ .. FACULTY OF MEDICINE \\ DEPARTMENT OF ANATOMY \\ BODY DONATION INFORMATION LEAFLET}

FACULTY

AMBLEM

- Bodies of deceased individuals that beeing used for learning the structure of the human body duringAnatomy courses are called as cadavers.

- Cadavers are widely used in undergraduate education of medical, dentistry, nursery, physiotherapy, and health sciences students. Additionally, they are vital for postgraduate education and scientificresearch studies.

- After your death, the Department will embalm and store your body in order to halt the decompsitionprocedure and facilitate education and research.

- Organs or limbs may be removed during educational or research activities performed on the body. Allthese procedures will be done by according to the highest care and attention all the time and respectingthe self-devotion of the donor.

- Organ and tissue samples may be collected from the body and evaluated with scientific methods foreducational and research purposes.

- Information gathered during these evaluations may be used in scienific publications, including articles,case presentations, reviews, and thesses.

- Digital images of the body, parts of the body, organs, and tissues may be acquired. These includephotographs, videos, three dimentional (3D) images, and 3D print-outs. Acquired images may be usedin scientific research studies and their subsequent scientific publications (articles, case reports, reviews, thesses, etc.), atlases/textbooks/lectures/presentation materials prepared with educational purposes, andcould be shared for academic purposes. Above mentioned activities will be done under ethicalguidelines in respect to the memory of the donor.

- Following required institutional permissions, the body may be transferred within or outside theinstitutions on condition that it will be returned to the Department.

- If death occurs at a place other than your residence, donation procedures may be performed bytransfering the body to the involved Department quickly or to the nearest institution with adequatefacilities for embalming.

- Sharing a copy of your health records with the Department is recommended for archiving, scientific,and safety purposes.

- Your donation may be declined by the Department due to predetermined reasons. The Department willexplain these reasons in detail before the donation aplication.

Appendix 1b

Body donation information leaflet in Turkish.

ÜNIVERSITE

LOGO
ÜNIVERSITESi

TIP FAKÜLTESI

ANATOMI ANABILIM DAL

BEDEN BAĞIŞI BiLGILENDIRME FORMU
FAKÜLTE

LOGO

- Insan bedeninin yapısını öğretmek amacı ile Anatomi dersleri kapsamında kullanılan cansız insan bedeninekadavra adı verilir.

- Kadavralar başta tıp, diş hekimliği, hemşirelik, fizyoterapi ve sağlık bilimleri öğrencilerinin lisanseğitiminde kullanılır. Ayrıca, uzmanlık ve uzmanlık sonrası eğitimleri ile bilimsel araştırmalarda dakullanılırlar.

- Eğitim ve araştırma yapılabilmesini sağlamak amacıyla bedeniniz bozulmasını engelleyecek ve AnabilimDalının uygun gördüğü bir yöntem ile tahnit edilir ve saklanır.

- Beden üzerinde yapılacak eğitim ve araştırma faaliyetleri sırasında organ ve uzuvlar çıkartılabilir. Ancak bu işlemler, bağışı gerçekleştiren kişinin fedakârlığını akılda tutarak gerekli özen ve saygıdan taviz vermeden gerçekleştirilir.

- Bedeninizden, eğitim ve araştırma amacıyla organ veya doku örnekleri alınabilir ve bilimsel yöntemlerlearaştırmalar yapılabilir.

- Araştırma sürecinde elde edilen veriler bilimsel yayınlarda (makale, olgu, derleme, tez vs.) kullanılabilir.

- Bedenin tamamının, bir bölümünün, organların ve dokuların dijital görselleri (fotoğraf, video, üç boyutlu(3B) görseller, 3D baskılar vs.) elde edilebilir. Elde edilen görseller; kişinin hatırasına saygı göstererek veetik kurallar çerçevesinde, bilimsel araştırmalar ve bunların sonucunda ortaya çıkacak bilimsel yayınlarda(makale, olgu, derleme, tez vs.) ve/veya eğitim amacı ile hazırlanan atlas/kitap/ders/sunum materyallerindekullanılabilir veya akademik amaçlarla paylaşılabilir.

- Gerekli kurumsal izinler alındıktan sonra bedeniniz, Anabilim Dalı’na geri getirilmesi şartı ile eğitim vearaştırma amacıyla kurum içinde veya kurum dışına nakledilebilir.

- Y Yaşamın, bağış işlemlerinizi yaptığınız şehirden çok uzak bir şehirde son bulması halinde, bağışınızıngerekleri bağış yaptığınız kuruma hızlıca nakledilmek sureti ile veya bedeninizin nakledilebileceği en yakınüniversitede gerçekleştirilebilir.

- Anabilim Dalı çalışanlarının sağlığı, arşivleme ve bilimsel araştırmalarda kullanım amacıyla sağlıkbilgilerinizin bir kopyasının Anabilim Dalı ile paylaşılmas gerekmektedir.

- Ayrıca bağışını, Anabilim Dalının belirlediği çeşitli nedenlerle kabul edilmeyebilir. Kabul edilmemesebepleri Anabilim dalı tarafından size ayrıntılı olarak anlatılacaktır. 
Appendix 2a

Body donation form in English.

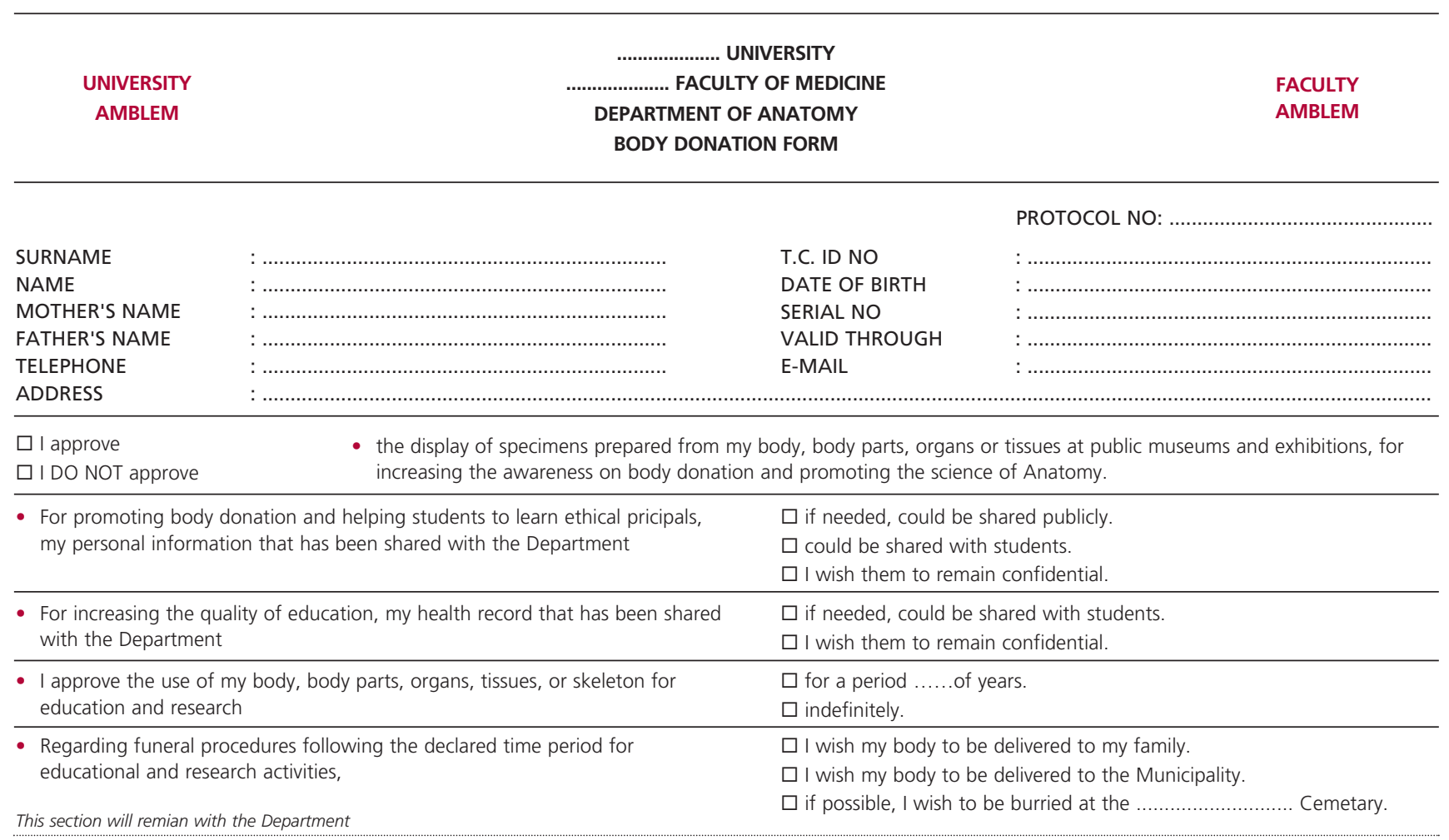

This section will remain with the donor

NOTE: Please carry this card next to your ID card.

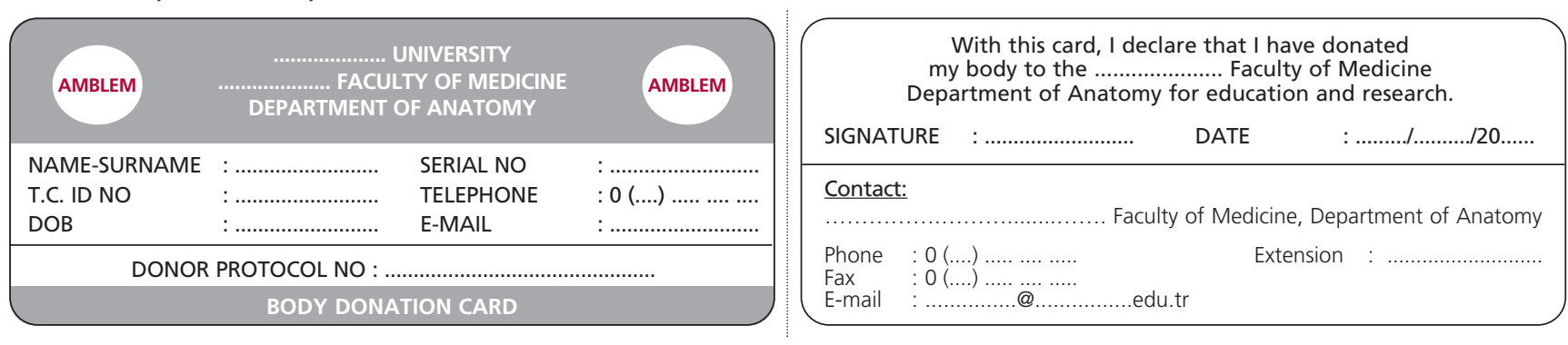

I, who have stated my ID openly with this minute, hereby declare that, I understood the information provided to me according to the Act on Organ and Tissue Harvesting, Storage, and Transplantation, dated 20.05.1979 and numbered 2238, and the Regulation on Performing Scientific Research on Human Corpse published in the Official Gazette dated 17.05.1982 and numbered 17727; with paying regard to all abovementioned declarations, following my death, I voluntarily donate my body to .................................. University, ............................ Faculty of Medicine Department of Anatomy, with my free will and without any pressure or expectation of any financial gain.

I have read this document and signed two copies in the presence of two witnesses.

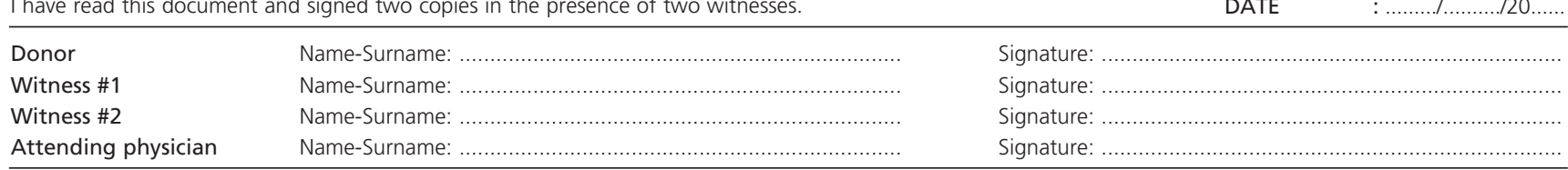

Individuals to be contacted if requested who are informed by the donor:

\begin{tabular}{|c|c|c|c|c|c|}
\hline Name-Surname: ................ & 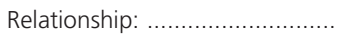 & Phone & $: 0(\ldots) \ldots \ldots \ldots \ldots$ & E-mail & : \\
\hline Name-Surname: ....... & 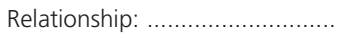 & Phone & $0(\ldots) \ldots \ldots \ldots \ldots$ & E-mail & \\
\hline
\end{tabular}

Contact information for .............. University .............. Faculty of Medicine Department of Anatomy:

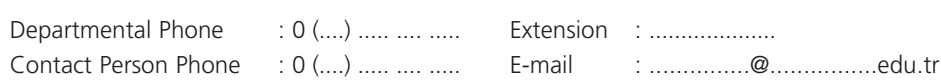

Address

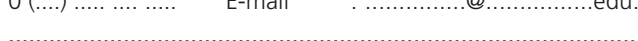

This section will remian with the Department

This section will remian with the donor 
